\title{
The Vitamin Nutrition of Zymomonas anaerobia
}

\author{
By M. P. STEPHENSON AND E. A. DAWES \\ Department of Biochemistry, University of Hull, Hull HU6 ${ }_{7} R X$ \\ AND M. J. S. DADDS AND P. A. MARTIN \\ Process Research Department, Allied Breweries (Production) Ltd, \\ Burton-on-Trent, Staffordshire
}

(Received I January 1973)

\section{INTRODUCTION}

Bexon \& Dawes (1970) reported that Zymomonas anaerobia NCIB 8227 grew in either amino acid or ammonium salt medium with glucose as the energy source, if supplemented with lipoic acid or biotin. Subsequently M. J. S. Dadds and P. A. Martin (unpublished observations) observed that calcium pantothenate supported growth of $Z$. anaerobia, but neither lipoic acid nor biotin did. The vitamin requirements of $Z$. anaerobia were therefore re-examined and the cultures maintained by the Hull and Allied Breweries Laboratories were compared with a new culture from the National Collection of Industrial Bacteria (NCIB).

\section{METHODS}

Three cultures of Zymomonas anaerobia $\mathrm{NCIB} 8227$ were used. Those designated $\mathrm{H}$ and $\mathrm{AB}$ were the stock cultures maintained by the Hull and Allied Breweries Laboratories respectively and $\mathrm{T}$ was newly obtained from the NCIB. All were maintained as stab cultures in nutrient agar containing $2 \%$ glucose (Hull) or in Difco micro assay culture agar (Allied Breweries).

Complex media and defined medium A were those described by Bexon \& Dawes (1970). Defined medium B was devised by Dadds and Martin and prepared from five solutions of the following compositions: (i) Basal salts (g/l): $\mathrm{KH}_{2} \mathrm{PO}_{4}, 10 ; \mathrm{MgCl}_{2} .6 \mathrm{H}_{2} \mathrm{O}, 4 \cdot 25$; $\mathrm{CaCl}_{2} .2 \mathrm{H}_{2} \mathrm{O}, 0.625 ; \mathrm{Na}_{2} \mathrm{SO}_{4}, \mathrm{I} \cdot 25$; citric acid. $\mathrm{H}_{2} \mathrm{O}, 2.75 ; \mathrm{Na}_{3}$-citrate. $2 \mathrm{H}_{2} \mathrm{O}, 13.0 ; \mathrm{NH}_{4} \mathrm{Cl}$, 4.75. (ii) Glucose, $20 \%(\mathrm{w} / \mathrm{v})$. (iii) Trace elements $(\mathrm{mg} / \mathrm{ml}): \mathrm{H}_{3} \mathrm{BO}_{3}, \mathrm{I} \cdot 00 ; \mathrm{ZnCl}_{2}, 0.34$; $\left(\mathrm{NH}_{4}\right)_{6} \mathrm{Mo}_{7} \mathrm{O}_{24} .4 \mathrm{H}_{2} \mathrm{O}, 0.20 ; \mathrm{CuCl}_{2}, 0.3 \mathrm{I} ; \mathrm{FeCl}_{3}, 3.40 ; \mathrm{MnCl}_{2}, 0.36$. This stock solution was diluted I0o-fold with distilled water. (iv) Amino acids (mg/l): L-tryptophan, I82; L-lysine, I28; L-histidine, 7I ; L-arginine, I68; L-aspartic acid, 82; L-threonine, 86; L-serine, 68; L-glutamine, 89; L-asparagine, 82; L-glutamic acid, I04; L-proline, 780; glycine, 36; Lalanine, II8; L-valine, I57; L-isoleucine, 93; L-leucine, I86; L-tyrosine, 146; L-phenylalanine, 193. (v) Vitamin solution: this contained the appropriate vitamin (biotin, lipoic acid or calcium pantothenate) at tenfold the final concentration to be used for growth.

Basal salts, amino acids and glucose solutions were sterilized separately at $103 \mathrm{kN} / \mathrm{m}^{2}$ $\left(15 \mathrm{lb} / \mathrm{in}^{2}\right)$ for $15 \mathrm{~min}$. The trace elements stock solution was sterilized at $103 \mathrm{kN} / \mathrm{m}^{2}$ and diluted with sterile distilled water. Vitamin solutions were sterilized by membrane filtration. The final medium was prepared by mixing the solutions in the following ratios $(\mathrm{v} / \mathrm{v})$ : basal salts, 4; amino acids, 2; diluted trace elements, I ; glucose, I ; vitamin, I. A Ringer-glucose solution containing $(\mathrm{g} / \mathrm{l}): \mathrm{NaCl}, \mathrm{r} .62 ; \mathrm{KCl}, 0.035 ; \mathrm{CaCl}_{2} .2 \mathrm{H}_{2} \mathrm{O}, 0.03 ; \mathrm{NaHCO}_{3}, 0.05$; $\mathrm{NaH}_{2} \mathrm{PO}_{4}, 0.0025$; glucose, 20, was used to wash and suspend harvested bacteria. 
Inocula. After growth for $48 \mathrm{~h}$ in complex medium $(20 \mathrm{ml})$, bacteria were harvested at room temperature $\left(20^{\circ} \mathrm{C}\right)$ using aseptic precautions, washed twice with $20 \mathrm{ml}$ sterile Ringer-glucose solution and suspended in this solution to give an extinction of approximately 0.6 at $540 \mathrm{~nm}$. This suspension was diluted Ioo-fold with sterile Ringer-glucose solution and $\mathrm{I} \mathrm{ml}$ used to inoculate $9 \mathrm{ml}$ of defined medium.

Growth conditions and measurements. Bacteria were grown in $150 \times 12 \mathrm{~mm}$ Pyrex tubes, containing $10 \mathrm{ml}$ of the appropriate medium, in a Fildes-McIntosh jar under $\mathrm{O}_{2}$-free nitrogen. When growth was complete, the cultures were transferred quantitatively to $20 \mathrm{ml}$ volumetric flasks, made to the mark with distilled water and the extinction measured at 540 and $580 \mathrm{~nm}$. The dry weight was then read from a calibration curve relating extinction to bacterial dry weight. Dry weights were determined by drying suspensions to constant weight at $100{ }^{\circ} \mathrm{C}$ or by filtering suspensions through predried membrane filters of known weight and weighing the loaded filter after drying over $\mathrm{P}_{2} \mathrm{O}_{5}$ under vacuum $(20 \mathrm{mmHg})$ at $46{ }^{\circ} \mathrm{C}$. The former method (Bexon \& Dawes, 1970) gave values which were 0.54 of the latter technique; all the present results are quoted on the basis of the filter method.

\section{RESULTS AND DISCUSSION}

A marked contrast was noted between the growth characteristics of the $\mathrm{H}$ strain and of the $\mathrm{AB}$ and $\mathrm{T}$ strains in complex medium. While the $\mathrm{AB}$ and $\mathrm{T}$ strains gave extensive wall growth, clumping and organisms which soon sedimented, the $H$ strain presented none of these features, the bacteria remaining in suspension for several days.

None of the strains grew in defined media with supplements of biotin or lipoic acid, singly or combined, whereas all organisms grew with calcium pantothenate. This is in direct contrast to the results of Bexon \& Dawes (I970). However, the AB and T strains, which behaved in a similar manner, both grew readily in the defined media. The $\mathrm{H}$ strain again differed markedly: growth was obtained with difficulty and often only after a lag of $\mathrm{I}$ to 7 days; often it failed to grow.

The growth response of the AB strain showed that calcium pantothenate was not limiting at concentrations above $0.025 \mu \mathrm{g} / \mathrm{ml}$. Attempts to determine the corresponding value for the $\mathrm{H}$ strain have been unsuccessful because of the irreproducible and apparently haphazard growth response below $0.5 \mu \mathrm{g}$ pantothenate $/ \mathrm{ml}$. This concentration gave a growth yield near to the maximum, with excess pantothenate, of $237 \mu \mathrm{g} / \mathrm{ml}$ - markedly lower than that obtained with the AB strain $(450 \mu \mathrm{g} / \mathrm{ml})$.

Clearly the Zymomonas anaerobia strains studied here require only pantothenate for growth in a defined medium. However, it is apparent that the culture maintained in Hull has undergone some change since it was originally obtained from the NCIB, as shown by the quantitatively and qualitatively different growth behaviour in complex and defined media in comparison with the $\mathrm{AB}$ and $\mathrm{T}$ strains. There is no obvious explanation for the entirely reproducible and well-documented results obtained by Bexon \& Dawes (1970) with biotin and lipoic acid using the $H$ strain other than a change in the strain characteristics. The organism did not then display the pronounced lag periods in defined medium which were a feature of this reinvestigation, although the maximum growth obtained with lipoate and biotin was in the range 250 to $274 \mu \mathrm{g} / \mathrm{ml}$, which compares quite favourably with that in pantothenate medium $(237 \mu \mathrm{g} / \mathrm{ml})$ and is very much lower than that of the $\mathrm{AB}$ and $\mathrm{T}$ organisms.

Further, two of us (M. J. S. Dadds and P. A. Martin, unpublished observations) have encountered an example of changed nutritional characteristics with a zymomonad isolated 
from beer. When first isolated this organism showed a requirement for $p$-aminobenzoic acid, folic acid, biotin and cyanocobalamine. After 5 months the vitamin requirements were re-examined. One of the subcultures from the original isolate did not require these vitamins but showed a requirement for calcium pantothenate. It seems possible, therefore, that Zymomonas species may present a variable nutritional character.

P. A. M. and M. J. S. D. wish to thank the Directors of Allied Breweries (U.K.) Limited for permission to publish this work.

\section{REFERENCE}

BEXon, J. \& DAWES, E. A. (1970). The nutrition of Zymomonas anaerobia. Journal of General Microbiology $60,421-425$. 